\title{
Pendidikan Sebagai Upaya Meningkatkan Kreativitas Perempuan Untuk Mendukung Pembangunan Berkelanjutan
}

\author{
Setyasih Harini \\ Email. setyasih.rini@gmail.com \\ Ganjar Widhiyoga \\ Email. Ganjar.widhiyoga@gmail.com \\ Universitas Slamet Riyadi Surakarta
}

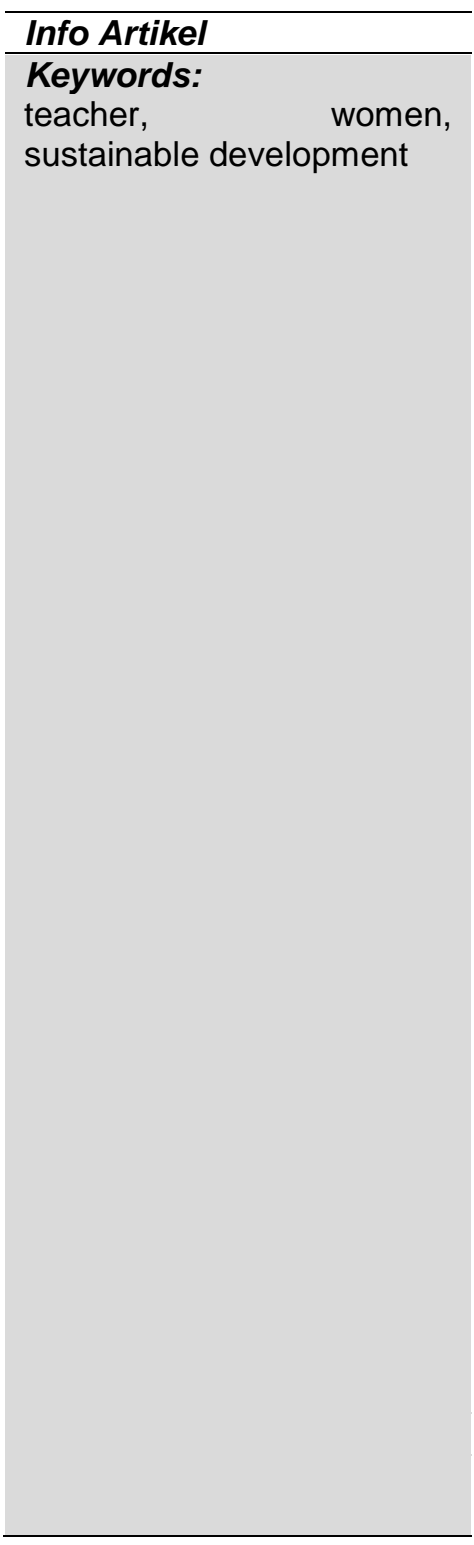

\begin{abstract}
Female teachers of SMK Negeri 4 Surakarta have not been able to fill sustainable development, especially in increasing their professionalism in making scientific work. This work is very important in addition to measuring the success of learning as well as to improve the analytical skills of teachers in dealing with problems in the classroom. The problems faced by partners are: (1) lack of understanding and insight into the importance of other libraries that can be used to add teaching material in the teaching and learning process; (2) female teachers are not yet motivated to arrange scientific work as demands that must be met as professionals; (3) not many female teachers take advantage of opportunities and opportunities to develop themselves and increase their creativity as educators to support sustainable development practices; (4) there are still teachers who have not utilized the existence of mass media as partners that can be used to accommodate scientific work to meet the requirements as certified teachers. The targets of the Community Service are as follows: (1) socializing the importance of scientific work as a manifestation of professionalism; (2) holding a meeting to increase the motivation of female teachers in making work of innovation and creativity in order to improve the learning process; (3) provide training in the formulation of opinions based on scientific articles to be uploaded to online mass media. Outputs that can be given through community service are as follows: (1) report on the results of service; (2) making articles for scientific publications that are submitted to the journal of the results of the service; (3) submitting articles to mass media. The method of implementation is through socialization, training, mentoring and motivation. The results of the implementation of the activity showed the enthusiasm and great interest of the female teachers in the socialization and training of the preparation of scientific publications including articles produced to be published in print and online mass media.
\end{abstract}

\section{PENDAHULUAN}

Pembangunan berkelanjutan salah satu elemennya adalah mengenai pendidikan. Di dalam programnya, terdapat pendidikan untuk mendukung praktek pembangunan berkelanjutan.

Dalam hal ini, pendidikan untuk mendukung praktek pembangunan atau yang dikenal dengan PPB berupaya untuk memberikan kesadaran dan kemampuan kepada semua orang untuk berkontribusi lebih banyak untuk pembangunan berkelanjutan. Untuk menunjang kegiatan guru dalam melaksanakan tugas pokoknya, seorang guru harus memiliki kualifikasi akademik, kompetensi, sertfikat pendidik, sehat jasmani dan rohani, serta memiliki kemampuan untuk mewujudkan tujuan 
pendidikan nasional. Demikian aturan yang tertuang dalam Perundang-Undangan No. 14 Tahun 2005 tentang Sertifikasi Guru. Regulasi tersebut, menjadikan guru bukan hanya sebagai pengajar yang membagikan ilmunya kepada para siswa namun juga pekerti yang baik. Pada sosok gurulah, masyarakat menitipkan dan mempercayakan anak-anaknya untuk mendapatkan pendidikan yang baik sebagai bekal masa depannya.

Kemampuan akademik yang telah diterima oleh seorang guru melalui pendidikan tinggi dan gelar kesarjanaanya hanya merupakan unsur penting bagi guru. Dengan pendidikan yang telah diterima, guru telah memiliki bekal secara akademik dan psikologis untuk membagi ilmunya dan memahami kharakter siswa yang dipercayakan kepadanya. Kesehatan jasmani dan rohani juga merupakan unsur penting lainnya karena seorang guru sebagai fasilitator dan motivator di dalam kelas. Guru sekaligus berperan sebagai aktor untuk menyelesaikan permasalahan yang dihadapi oleh para peserta didik.

Keberpihakan pemerintah terhadap dunia pendidikan khususnya kesejahteraan bagi para guru telah dimulai sejak 30 Desember 2005 dengan dikeluarkannya Undang-Undang Sertifikasi Guru. Pengalaman dan sejarah sebelum dikeluarkannya perundangan tersebut, nasib guru dapat diibaratkan seperti pepatah sudah jatuh, tertimpa tangga, kurang menguntungkan. Julukan guru sebagai "Oemar Bakrie" begitu kental terdengar di masyarakat mengingat kesejahteraannya yang kurang mendapat perhatian dari pemerintah waktu itu. Kala itu pelayanan, pengorbanan dan perjuangan para guru tidak sepadan dengan imbalan yang didapatkannya. Kondisi seperti ini lebih terasa bagi para guru yang mendapat tugas di daerah pedesaan.

Sekilas perlu diingat gagasan dari Boateng (2016) yang menyatakan bahwa globalisasi lebih dimaknai sebagai sebuah masa yang menunjukkan pertumbuhan mobilitas internasional dari berbagai produk, jasa, modal, fasilitas maupun manusia. Tingginya mobilitas tersebut didukung oleh praktik liberalisme dan privatisasi yang di dalamnya diwarnai dengan tingginya kompetisi. Kompetisi diantara para pelaku bukan hanya sebatas terhadap kepemilikan sumber daya, kekuasaan, pasar namun juga kompetisi jasa (pelayanan). Sementara, jika dilihat pada pelaksanaan pendidikan yang berlaku di Indonesia banyak fakta yang menunjukkan institusi formallah yang dipercaya meningkatkan kualitas kehidupan. Rusniati (2015) justru melihat bahwa pelaksanaan pendidikan Indonesia ketika masuk dalam era globalisasi masih diwarnai dengan pengembangan kecerdasan secara sempit sehingga kurang memberikan kesempatan bagi peserta didik untuk meningkatkan kreativitas dan inovasinya. Dalam situasi semacam ini, guru masih menduduki posisi sebagai yang utama dan terutama terhadap pengembangan belajar mengajar siswa di dalam kelas.

Gambaran tersebut juga dialami oleh para guru perempuan dari Sekolah Menengah Kejuruan (SMK) Negeri 4 Surakarta. Dalam tahun ajaran 2018/2019 ini, SMK Negeri 4 Surakarta telah memiliki guru sejumlah 81 orang yang terdiri dari 57 perempuan dan sisanya laki-laki. Untuk peserta didik lakilaki berjumlah 172 orang sedangkan yang perempuan adalah 1.097 orang. Kompetensi bagi para peserta didik yang ditawarkan dari sekolah adalah akomodasi perhotelan, tata boga, tata busana dan tata kecantikan. Hasil survei yang telah dilakukan oleh Tim Pengabdian dari Universitas Slamet Riyadi Surakarta pada tanggal 20 Pebruari 2018 menunjukkan bahwa lulusan dari sekolah ini telah terserap dengan baik dan mendekati target maksimal di dunia industri. Untuk jurusan perhotelan, banyak alumnus yang telah mendapatkan pekerjaan di berbagai hotel ternama di Kota Surakarta antara lain Hotel Aziza, Sahid Kusuma, dan Aston. Untuk lulusan tata boga dan busana selain mendapat pekerjaan di industri kuliner dan konveksi ada yang justru membuka wirausaha sendiri di rumahnya. Lulusan tata kecantikan banyak yang bekerja di salon ataupun industri termasuk Larissa, Natasha dan usaha sendiri.

Dari lulusan yang berhasil mendapatkan pekerjaan tersebut sepertinya sekolah vokasi saat ini telah mendapatkan tempat di masyarakat. Hal ini tidak terlepas dari peran guru sebagai tenaga pengajar yang menjadi inspirator, fasilitator dan motivator bagi para siswanya. Untuk meningkatkan kemampuan guru agar mendapatkan lulusan yang diharapkan tersebut, guru tidak hanya mengandalkan pada ilmu yang telah diterimanya namun juga perlu dikembangkan. Sampai saat ini, masih banyak masyarakat yang menaruh kepercayaan dan harapan besar kepada guru sebagai aktor yang mampu menyebarkan virus positif dalam bentuk pengetahuan, pengalaman, dan ketrampilan kepada peserta didiknya. Kemampuannya dalam memberikan dan menularkan pengetahuan kepada generasi muda menjadikan gelar guru sangat dihormati. Guru yang masih aktif pada masa milenial sekarang ini memiliki beban dan tanggung jawab yang lebih besar dibanding pada masa sebelumnya. Dalam Pasal 10 Undang-Undang No. 14 Tahun 2005 mengenai Sertifikasi Guru dan Dosen dijelaskan 
bahwa seorang guru hendaknya memiliki kompetensi pada bidang pedagogik, kepribadian, sosial, dan profesional melalui pendidikan profesi.

Permasalahan yang dihadapi oleh mitra adalah: pertama, kurangnya pengertian dan wawasan akan pentingnya pustaka lain yang bisa digunakan untuk menambah bahan ajar dalam proses belajar mengajar. Kedua, guru-guru perempuan belum termotivasi untuk menyusun karya ilmiah sebagai tuntutan yang harus dipenuhi sebagai tenaga profesional. Ketiga, guru perempuan belum banyak yang memanfaatkan peluang dan kesempatan untuk mengeembangkan diri dan meningkatkan kreativitasnya sebagai pendidik guna mendukung praktek pembangunan berkelanjutan. Keempat, masih adanya guru yang belum memanfaatkan keberadaan media massa sebagai partner yang dapat digunakan untuk mewadahi karya ilmiah guna memenuhi ketentuan sebagai guru tersertifikasi.

Seperti yang telah diuraikan sebelumnya bahwa tujuan dari PPB adalah menjadikan pendidikan sebagai lembaga yang berakhlak mulia dari usia dini sampai perguruan tinggi. PPB juga berupaya untuk menekankan pada aktivitas berupa pemikiran global namun aksiny pada tataran lokal (Ngabekti, 2012). Pendidikan dipilih sebagai implementasi pembangunan berkelanjutan karena merupakan instrumen yang kuat, mengakar dan efektif untuk selalu berkomunikasi, membagi informasi, penyadaran serta pembelajaran yang dapat memobilisasi massa atau komunitas. Selain itu pendidikan juga instrumen untuk menggerakkan bangsa ke arah kehidupan guna mempersiapkan masa depan yang secara berkelanjutan lebih baik. Untuk itu perlu menjadikan semua elemen masyarakat sebagai mitra untuk mengisi pembangunan berkelanjutan termasuk perempuan.

Duman (2012) menjelaskan bahwa perempuan sebagai bagian dari masyarakat hendaknya memiliki peran yang sama dengan laki-laki. Dari pernyataan tersebut, Duman hendak menyampaikan sebuah pesan bahwa perempuan mestinya mendapatkan kesempatan dan penghargaan yang sama dengan laki-laki. Masyarakat terlebih dari negara-negara berkembang justru lebih sering menempatkan perempuan pada label negatif dibandingkan dengan laki-laki. Perempuan kurang mendapat kesempatan untuk mengimplementasikan potensi dan kemampuannya sendiri. Di sisi lain, masyarakat hendaknya juga diberikan edukasi dalam bentuk pemahaman sehingga tidak lagi atau setidaknya memberikan porsi yang sama antara perempuan dan laki-laki dalam berbagai aktivitas. Masyarakat sekaligus diharapkan juga memberikan kepercayaan kepada perempuan untuk berperan lebih banyak sesuai dengan harkat dan martabatnya.

Untuk itu melalui pengabdian ini bertujuan untuk (1) meningkatkan pengetahuan bagi sebagian guru perempuan dari SMK Negeri 4 Surakarta akan pentingnya memanfaatkan internet secara bijaksana guna menunjang proses belajar mengajar di kelas; (2) meningkatkan kemampuan menulis karya ilmiah dalam bentuk publikasi; (3) meningkatkan kemampuan kepada guru-guru perempuan untuk mempublikasikan karya ilmiahnya pada media massa. Adapun target dari pengabdian ini adalah: (1) memberikan sosialisasi kepada para guru perempuan dalam memanfaatkan teknologi informasi dan komunikasi secara bijaksana guna memperlancar dan menunjang proses belajar mengajar; (2) memberikan pelatihan pembuatan karya ilmiah kepada para guru perempuan; (3) memberikan motivasi dan pendampingan kepada para guru perempuan untuk mempublikasikan karya ilmiah ke media massa. Luaran dari pengabdian ini adalah: (1) pembuatan laporan hasil pengabdian; (2) pembuatan artikel untuk publikasi ilmiah yang dimasukkan ke dalam jurnal hasil pengabdian; (3) memasukkan artikel dalam bentuk opini ke media massa online.

\section{METODE PELAKSANAAN}

Dalam melaksanakan pengabdian kepada masyarakat ini, yang menjadi mitra adalah SMK Negeri 4 Surakarta khususnya guru-guru perempuannya. Dengan adanya permasalahan tersebut maka solusi yang ditawarkan menggunakan metode sebagai berikut: 1) memberikan edukasi dalam bentuk sosialisasi kepada para guru perempuan akan pentingnya memanfaatkan berbagai pustaka secara manual dan online sebagai media pembelajaran 2) Tim Pengabdian memberikan pelatihan dalam menyusun artikel ilmiah berdaarkan pada penelitian yang telah dibuat yakni Penelitian Tindakan Kelas atau PTK 3) Tim Pengabdian memberikan pelatihan editing karya ilmiahnya menjadi sebuah tulisan untuk dipublikasikan ke media massa.

Dalam melaksanakan pengabdian kepada masyarakat ini, Tim Pengabdian memiliki kepakaran dalam pembuatan karya ilmiah yang dibantu oleh tenaga ahli dari ilmu pendidikan. Untuk yang pembuatan karya ilmiah, Tim Pengabdian memiliki latar belakang 
pendidikan IImu Hubungan Internasional dengan mata kuliah yang diampu adalah Metode Penelitian, Gender dan Pembangunan. Sementara dosen dengan latar belakang pendidikan Taknik Informatika diperbantukan untuk memberikan sosialisasi mengenai pemanfaatan teknologi komunikasi dan informasi (internet) secara bijaksana. Pembentukan dan pembagian tugas tersebut dimaksudkan untuk mempermudah pelaksanaan kegiatan pengabdian yang diawali dengan sosialisasi, pelatihan, pendampingan dan pemberian motivasi bagi para guru mulai dari penyusunan artikel ilmiah dan pengiriman karya tersebut ke media massa.

\section{HASIL PELAKSANAAN KEGIATAN}

Pemberdayaan perempuan dalam pembangunan berkelanjutan sangat diperlukan. Pemberdayaan perempuan tersebut dapat diwujudkan dalam berbagai bidang khususnya pendidikan. Pola asuh dan pendidikan bagi anak sebagai bekal masa depannya sangat ditentukan oleh peran seorang perempuan baik ibu maupun guru. Studi dari Islahi (2013) menunjukkan bahwa perempuan yang berperan sebagai guru memiliki korelasi positif terhadap perkembangan anak dan ini sangat dibutuhkan dalam pembangunan berkelanjutan untuk meningkatkan human index. Guru perempuan diharapkan memiliki kemampuan untuk lebih supportif, ekspresif, lebih informal, supel dan terbuka kepada murid dibanding tenaga pengajar laki-laki.

Lebih lanjut, Jackie (2008) memberikan sebuah bukti adanya korelasi antara jumlah guru-guru perempuan dengan banyak sedikitnya murid untuk bersekolah. Gambaran yang diberikan oleh Jackie lebih difokuskan pada anak-anak usia sekolah di sub-Sahara Afrika, Afghanistan, Pakistan, Bangladesh dan Nepal. Menurutnya semakin banyak guru yang berkelamin perempuan semakin tinggi tingkat kepercayaan orang tua untuk menyekolahkan anaknya. Kepercayaan yang tinggi kepada guru perempuan lebih didasarkan pada sifat atau watak yang dimilikinya seperti sabar, perhatian, dan memiliki perasaan seperti ibu dari siswa yang bersangkutan. Berdasarkan dua gagasan tersebut dapat ditarik benang merah bahwa guru perempuan jika diberi kepercayaan dapat mengembangkan potensi dan naluri keibuannya. Naluri tersebut dibawa serta ketika berhadapan dengan para peserta didik.

Bidang gender dan pembangunan membutuhkan adanya pemahaman pada permasalahan sosial dan humaniora. Upaya meningkatkan bidang sosial humaniora salah satunya dilakukan melalui pendidikan formal. Kegiatan pengabdian kepada masyarakat dengan mitra guru-guru SMK $\mathrm{N} 4$ Surakarta dilaksanakan pada tanggal 2-30 Juli 2018. Kegiatan tersebut diawali dengan memberikan sosialisasi kepada para guru perempuan. Sosialisasi tersebut dilaksanakan pada tanggal 2 Juli dengan tujuan untuk memberikan wawasan kepada para guru perempuan pentingnya pemanfaatan pustaka manual dan online sebagai alternatif media pembelajaran. Sosialisasi berikutnya membahas mengenai pentingnya karya ilmiah bagi seorang guru. Artikel ilmiah ini dibuat berdasarkan pada riset sebelumnya yang dikenal dengan Penelitian Tindakan Kelas (PTK). Pada umumnya riset PTK ini dilaksanakan untuk mengatasi atau menyelesaikan permasalahan yang dihadapi guru selama proses pembelajaran di kelas.

Kegiatan sosialisasi ini hanya dilaksanakan dua hari dengan waktu dari jam 08.00-13.00. Waktu tersebut cukup memadai dan efektif untuk memberikan wawasan mengenai (1) pentingnya sumber dan media pembelajaran selain buku; (2) artikel ilmiah yang bisa dipublikasikan secara cetak maupun online. Artikel ilmiah yang dipublikasikan tersebut sangat membantu bagi para guru yang telah menerima sertifikasi pendidik profesional. Dalam kegiatan sosialisasi ini diikuti oleh 36 guru dari latar belakang bidang pengajaran yang beragam. Acara sosialisasi dibuka oleh Kepala Sekolah yang diwakilkan oleh Wakil Kepala Sekolah bidang Kurikulum. Sambutan yang disampaikan oleh Wakil Kepala Sekolah pada dasarnya berisikan motivasi kepada para guru terutama yang telah menerima sertifikasi guru untuk lebih meningkatkan profesionalismenya terutama dengan aktif menulis. Dalam acara ini juga dihadiri oleh perwakilan dari Dinas Pendidikan Kota Surakarta. Sambutan dari Dinas Pendidikan pada dasarnya juga menandaskan kepada para guru untuk lebih aktif dan kreatif dengan mencari inovasi baru untuk membuat pembelajaran yang lebih menyenangkan.

Pembelajaran yang menyenangkan tersebut sangat diharapkan oleh para peserta didik saat ini mengingat godaan dan tantangan siswa dalam mengikuti proses belajar mengajar semakin banyak. Salah satunya adalah penggunaan gadget yang kurang bijaksana, pengaruh negatif dari teman atau lingkungan dan sebagainya yang semuanya bermuara pada lemahnya semangat untuk mengikuti 
pembelajaran dan kurangnya penghormatan atau kepatuhan terhadap orang yang lebih tua. Kesemuanya ini penting dalam proses pembangunan moral yang sedang dilaksanakan oleh Negara Indonesia. Melalui pembangunan moral yang terus-menerus diberikan dan disebarluaskan dalam kerangka pendidikan formal diharapkan dapat meningkatkan budi pekerti atau karakter bagi generasi muda bangsa.

Pemberdayaan perempuan dalam pembangunan berkelanjutan sangat diperlukan. Pemberdayaan perempuan tersebut dapat diwujudkan dalam berbagai bidang khususnya pendidikan. Pola asuh dan pendidikan bagi anak sebagai bekal masa depannya sangat ditentukan oleh peran seorang perempuan baik ibu maupun guru. Studi dari Islahi (2013) menunjukkan bahwa perempuan yang berperan sebagai guru memiliki korelasi positif terhadap perkembangan anak dan ini sangat dibutuhkan dalam pembangunan untuk meningkatkan human index. Guru perempuan diharapkan memiliki kemampuan untuk lebih supportif, ekspresif, lebih informal, supel dan terbukan kepada murid dibanding tenaga pengajar laki-laki.

Penelitian Tindakan Kelas yang telah dilakukan oleh guru-guru SMK N 4 Surakarta selama ini kurang maksimal. Tidak sedikit guru yang telah mengikuti pelatihan dan workshop untuk menyusun riset namun selain karena minat yang kurang juga tugas administratif dan beban mengajar yang tinggi menjadi alasan rendahnya penelitian. Penelitian selama ini yang telah dihasilkan oleh para guru perempuan tersebut berkaitan dengan strategi untuk meningkatkan semangat belajar karena metode pengajaran yang masih konvensional. Penelitian guru belum menyentuh pada pengaruh yang dihasilkan dari kemajuan teknologi komunikasi dan informasi terutama internet yang bisa diakses melalui gadget. Akibat globalisasi yang berkaitan dengan teknologi internet ini memiliki pengaruh yang besar terhadap siswa yang belum sempat mendapat pembekalan untuk memanfaatkannya secara bijaksana.

Untuk proses pelatihan dan pendampingan kepada para guru perempuan dalam membuat karya ilmiah dimulai sejak tanggal 4-25 Juli 2018. Pelatihan dilakukan dalam dua kali tatap muka dalam sepekan dari jam 14.00-17.00. Pelatihan dimulai dengan masing-masing peserta menunjukkan hasil risetnya. Pada pekan kedua, setiap peserta masuk ke dalam kluster sesuai bidang studi yang diajarkan untuk saling memahami permasalahan dalam riset. Pada pekan ini para peserta sekaligus menyusun karya ilmiah. Berdasarkan pada pengamatan dan evaluasi yang dilakukan oleh Tim Pengabdian terhadap para peserta menunjukkan adanya motivasi tinggi untuk menyusun karya ilmiah yang dapat dipublikasikan. Riset yang telah dibuat dengan tujuan untuk mengatasi atau menyelesaikan permasalahan kelas tidak hanya disimpan namun disebarluaskan melalui artikel ilmiah. Sebagian besar peserta (30) menyatakan menerima manfaat dari pelatihan penyusunan artikel ilmiah ini hanya enam orang yang masih merasa kesulitan dalam penyusunan artikel ilmiah sehingga masih mendapat bimbingan dan pendampingan di luar program ini. Dengan artikel ilmiah yang dipublikasikan ke dalam jurnal dan media massa baik cetak maupun online dapat memberikan gambaran kepada para guru akan karya kreatifitas dan inovasinya yang telah dibuat.

Setelah pelatihan yang diberikan kepada para guru perempuan terkait penyusunan artikel untuk publikasi ilmiah selesai, Tim Pengambdian tetap memberikan motivasi dan pendampingan lebih lanjut terlebih masih adanya peserta yang belum mampu. Motivasi dan pendampingan ini diberikan kepada para guru agar menyusun kembali artikel ilmiah tersebut dan dikemas seperti tulisan opini untuk dikirimkan ke media massa cetak atau online. Media massa cetak yang dipilih dalam pelatihan ini adalah Majalah Pendidikan dan Keluarga GENTA. Pemilihan ini didasarkan pada sebuah alasan bahwa majalah tersebut langsung terkait dengan pendidikan formal mulai dari tingkat dasar hingga menengah atas. Untuk media massa online yang siap menerima karya guru pada wilayah Surakarta dan sekitarnya adalah Poskita.co yang di dalamnya terdapat ruang pendidikan dalam bentuk opini atau kolom. Tim Pengabdian dan perwakilan peserta memonitor artikel yang masuk ke media massa agar segera ditindaklanjuti untuk dipubllikasikan. Kegiatan ini diselenggarakan pada pekan terakhir yakni tanggal 25-29 Juli.

Berdasarkan pada evaluasi yang telah dilakukan oleh Tim Pengabdian dengan mitra yang dalam hal ini adalah SMK N 4 Surakarta terdapat beberapa catatan penting yakni: (1) para peserta sangat antusias terdapat program kegiatan pelatihan dan pendampingan ini karena terkesan lebih santai dan komunikatif antara pihak pelatih dan yang dilatih; (2) pelatihan ini sekaligus sebagai ajang bertukar informasi, wawasan dan pengalaman diantara para guru; (3) guru perempuan yang selama ini kurang kreatif, inovatif dan komunikatif menjadi lebih berani mencoba sesuatu yang baru; (4) beberapa guru merasa lebih diberdayakan dan diasah kemampuan dan potensinya; (5) beberapa 
peserta bahkan menjelaskan bahwa dengan mengikuti pelatihan tersebut memberikan kesempatan untuk berpartisipasi dalam proses pembangunan manusia yang berkelanjutan.

\section{KESIMPULAN}

Program kegiatan pengabdian kepada masyarakat yang dilaksanakan dengan mitra dari SMK N 4 Surakarta memberikan kontribusi yang positif. Kontribusi positif tersebut dialami oleh para guru perempuan baik yang telah menerima sertifikasi maupun yang belum. Bagi guru-guru muda, pelatihan ini memberikan pengalaman baru untuk termotivasi belajar membuat publikasi ilmiah sendiri. Bagi guru-guru yang telah menerima sertifikasi, pelatihan ini mendorongnya untuk lebih banyak melakukan Penelitian Tindakan Kelas guna mengatasi permasalahan pembelajaran. Melalui penulisan artikel ilmiah yang dipublikasikan menjadi sebuah kesempatan bagi para guru perempuan untuk berperan dalam proses pembangunan manusia yang berkelanjutan.

\section{REFERENCES}

Boateng, Oti, (2016). Ensuring The Central Role of Women in Development, International Journal of Gender and Women's Studies, Vol 4 No. 2 (11-24).

Duman, Fatih, (2012). The Roots of Modern Feminism: Marry Wollstonecraft and the French Revolution, International Journal of Humanities and Social, Vol. 2, No.9 (75-89), University of Turkey.

Islahi, Fatima dan Nasreen (2013). Who Make Affective Teachers: Men or Women an Indian Perspectives, Universal Journal of Educational Research 1(4), (285-293).

Jackie, Kerk (2008). The Impact of Women Teacher toward Girl's Education, Bangkok: UNESCO Asia and Pasific Regional Bureau for Education.

Monkman, Karen, (2011). Framing, Gender, and Development, Research in Comparative and International Education, Vol. 6, No.1 (1-13).

Rusniati, (2015). Pendidikan Nasional dan Tantangan Globalisasi: Kajian Kritis terhadap Pemikiran A. Malik Fajar, Jurnal IImiah Didaktika, Vol. 16. No. 1 (105-128).

Ngabekti, Sri, (2012). Konsep Pendidikan Untuk Pembangunan Berkelanjutan (Kasus Pondok Pesantren Modern Selamat Kendal), Disertasi, Sekolah Pascasarjana Universitas Gadjah Mada Yogyakarta. 